\title{
Facile Coating of HAP on Ti6Al4V for Osseointegration
}

\author{
Shafaq Asrar \\ Department of Metallurgical Engineering \\ NED University of Engineering and Technology \\ Karachi, Pakistan \\ shafaqfara@neduet.edu.pk
}

\author{
Muhammad Tufail \\ NED University of Engineering and Technology \\ Karachi, Pakistan \\ mtufail@neduet.edu.pk
}

\author{
Ali Dad Chandio \\ Department of Metallurgical Engineering \\ NED University of Engineering and Technology \\ Karachi, Pakistan \\ alidad@neduet.edu.pk
}

\begin{abstract}
Ti6Al4V alloy is a material with great strength, lowslung modulus, inferior density, and a virtuous blend of mechanical and exceptional corrosion resistance. However, it does not offer good osseointegration and bone development properties. Conversely, hydroxyapatite (HAP) is highly bioactive in nature to bind with the nearby bone tissues when implanted in the host body. In this work, we have extracted HAP from bovine bones by using the thermal decomposition method. This was followed by its deposition onto the Ti6Al4V alloy using the Electrophoretic Deposition (EPD) technique. $\mathrm{TiO}_{2}$ is used as a bond coat layer to increase the adhesion between HAP and Ti6Al4V alloy substrates. The coated samples after sintering exhibited excellent adhesion. This was followed by characterization using Scanning Electron Microscopy (SEM) and Fourier Transformed Infrared Spectroscopy (FTIR). FTIR and SEM confirm the formation of HAP and its presence after the immersion in SBF. Vicker hardness tester confirms the increase in hardness value of coated samples up to $35 \%$. Potentiostat tests were conducted to compare the corrosion rate of both samples. In addition, the particle sizes were also identified by a laser particle analyzer, whereas X-Ray Diffraction (XRD) technique was also used to determine the crystalline phases of alloy and HAP.
\end{abstract}

Keywords-corrosion; electrophoretic deposition; hydroxiapatite; simulated body fluid; Ti6 Al4V alloy

\section{INTRODUCTION}

Materials having biotic nature or host tissue compatibility can be implanted into living organisms to augment or replace impaired parts. Generally, metals, ceramics, polymers, and composites are materials widely used in biomedical applications. Amongst them, titanium-based alloys are some of the most widely used as implant materials [1]. Titanium and its alloys bear enhanced properties like excellent strength [2], optimum elastic modulus [3], low density [4], blend of other mechanical properties [5], and excellent corrosion resistance [6-12], needed for various applications including orthopedic
[13], dental [14], and surgical implants [15], artificial joints [15], etc. It should be noted that the elastic modulus of titanium-based alloys is considerably close to bones' $[16,17]$ which makes it ideal for long term applications [18]. However, titanium based alloys do not possess good osseointegration [19] thereby requiring additional surface treatment. This means that there is a poor bond between titanium and bones causing implant loosening which is highly undesirable. Therefore, surface modification plays a vital role in optimum osseointegration $[15,20]$. There are several techniques used in this regard such as: sand blasting [21, 22], etching [23], electrochemical treatment [24], and thermal spray coatings [25]. Amongst them, bio-ceramic coatings using, the hydroxyapatite (HAP - $\left.\mathrm{Ca}_{10}\left(\mathrm{PO}_{4}\right)_{6}(\mathrm{OH})_{2}\right)$ [26-28] are very promising for the modification of implant surfaces since they create strong bonding with bones [29-31]. One of the great advantages of the HAP is its great lifespan [32, 33]. The calcium phosphate $(\mathrm{CaP})$ ratio of HAP is 1.67 which is highly stable at a normal temperature and its $\mathrm{pH}$ ranges from 4 to 12 . However, the properties and resultant applications of HAP depend on morphology, size, chemical composition and crystallinity [31]. In addition, it provides speedy and durable fixation to the host bones and possesses osseoconductive properties [34], protecting the metal surfaces from the environmental effects and thereby reducing the discharge of metallic ions from the implant surface to the host body. The main advantage of $\mathrm{CaP}$ is that it is already present in the bones and teeth of the vertebrates [35]. Moreover, there are several methods to produce HAP such as: dry methods, wet methods, microwave (MW)-assisted methods, ball-milling or ultrasound, etc. [36]. Additionally, numerous coating strategies are available to coat HAP on metallic alloys, for instance: plasma spraying [37, 38], sol gel [39, 40], Electrophoretic Deposition (EPD) $[11,41-43]$, etc. Amongst them the most economically viable technique is EPD [44], offering a controlled coating composition with the process being highly pure [45], fast [41] 
that could be used to coat complex shaped substrates [45]. In this study, HAP was produced from bovine bones since they are an abundant and economical source. This was followed by the deposition of HAP on chemically treated Ti6Al4V alloy.

\section{EXPERIMENTAL PART}

\section{A. Materials}

The materials utilized in this research are shown in Table I. All of them were of analytical grade and were used in as received condition.

TABLE I. MATERIALS/CHEMICALS USED

\begin{tabular}{|c|c|c|c|}
\hline S.No. & Chemicals / materials & $\begin{array}{c}\text { Purity } \\
\mathbf{( \% )}\end{array}$ & Supplier \\
\hline 1 & Ti-6Al-4V & 99.0 & $\begin{array}{c}\text { Baoji North Hongsheng } \\
\text { Industry \& Trade Co., Ltd. }\end{array}$ \\
\hline 2 & Sodium chloride & 99.0 & Sigma Aldrich \\
\hline 3 & Sodium bicarbonate & 99.0 & Sigma Aldrich \\
\hline 4 & Potassium chloride & 99.0 & Sigma Aldrich \\
\hline 5 & $\begin{array}{c}\text { Di sodium phosphate } \\
\text { tri hydrate }\end{array}$ & 99.0 & Sigma Aldrich \\
\hline 6 & $\begin{array}{c}\text { Magnesium chloride } \\
\text { hexa hydrate }\end{array}$ & 99.0 & Sigma Aldrich \\
\hline 7 & Hydrochloric acid & 99.0 & Sigma Aldrich \\
\hline 8 & $\begin{array}{c}\text { Calcium chloride } \\
\text { dehydrate }\end{array}$ & 99.0 & Sigma Aldrich \\
\hline 9 & Di sodium sulphate & 99.0 & Sigma Aldrich \\
\hline 10 & $\begin{array}{c}\text { Cyano hydride tri } \\
\text { methanol }\end{array}$ & 99.0 & Sigma Aldrich \\
\hline
\end{tabular}

\section{B. Methods}

\section{1) Preparation of Hydroxyapatite}

HAP was synthesized from bovine bones, purchased from the local market, by the thermal decomposition process. This was followed by their boiling in deionized water for about 3 hours to remove the unwanted fats. Additionally, second boiling was carried out for the deproteinization of bones. Thereafter, the bones were immersed in acetone for two hours in an ultrasonic bath for further cleaning. Subsequently, the bones were dried and cut into smaller sizes by mortar and pestle. The resultant powder was placed into a box furnace and heated at $1100^{\circ} \mathrm{C}$ at a heating rate of $5^{\circ} \mathrm{C} / \mathrm{min}$ for 3 hours for the preparation of HAP. Later on, XRD and laser particle analysis were conducted to confirm the peaks and particle sizes of as-synthesized HAP powders respectively. The process details are shown in Figure 1.

\section{2) Activation of Substrates}

Titanium alloy Ti6A14V was used as substrate in plate form, having a thickness of $2 \mathrm{~mm}$. The microstructure of the asreceived $\mathrm{Ti}$ alloy was revealed by following the steps of grinding and polishing followed by etching for $20-25 \mathrm{~s}$ in the Kroll's reagent $(96 \mathrm{ml}$ distilled water $+6 \mathrm{ml} \mathrm{HNO} 3+2 \mathrm{ml} \mathrm{HF})$. A wet chemical etching process was carried out to enhance the surface available for coating at room temperature. Several chemicals were used to immerse the electrode into the solution for the desired time and then it was ready to be used as a substrate for coating. Next, we took an equal quantity of $5 \mathrm{ml}$ each for hydrochloric acid, nitric acid, hydrogen peroxide, sulfuric acid and introduced them into $30 \mathrm{ml}$ of distilled water followed by the immersion of substrates into the prepared solution for 3 hours. Then, titanium substrates were placed in 5 Molar $\mathrm{NaOH}$ solutions for 72 hours at room temperature. In the next step, the substrates were annealed in the air using a box furnace at $600 \mathrm{C}$ followed by holding for 1 hour. This process was used to create the small nano-sized pits on the surface of the substrates used for the coating purpose. The samples were then considered ready for the EPD process.

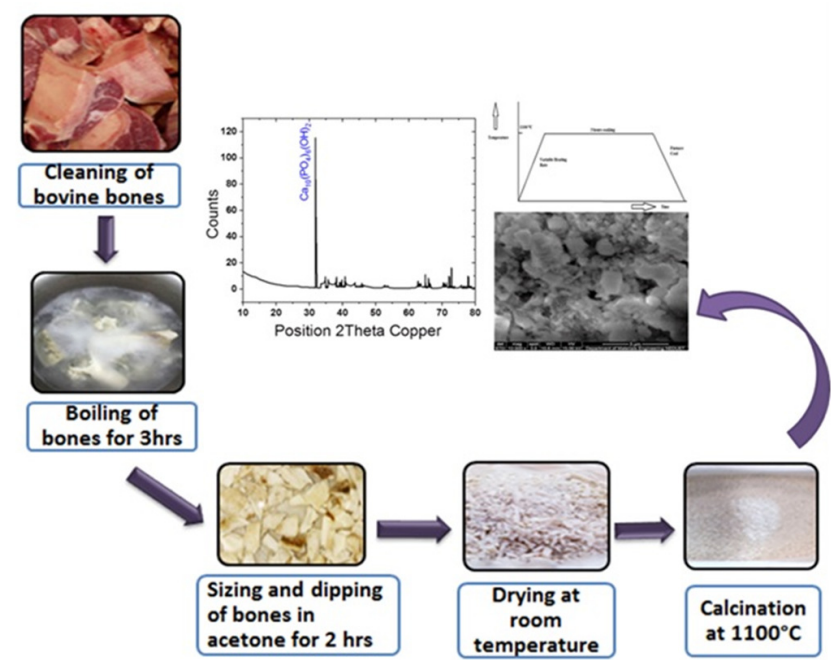

Fig. 1. Steps of producing HAP from bovine bones, calcination cycle, and XRD pattern of successfully produced HAP.

\section{3) EPD of HAP}

For the enhancement of adhesion properties of hydroxyapatite, Titania $\left(\mathrm{TiO}_{2}\right)$ was used as an intermediate layer between HAP and Titanium alloy substrate. The process flow chart is shown in Figure 2. In this process, an electrolytic solution containing $0.5 \mathrm{~g} \mathrm{TiO}_{2}$ and $0.5 \mathrm{~g}$ HAP was dissolved in $100 \mathrm{ml}$ ethanol solution followed by sonication for 15 minutes and was ultrasonically shook for 30 minutes. It was then left for settling for 20 minutes and was stirred again for 25 minutes at $40^{\circ} \mathrm{C}$. The EPD process was done at $20 \mathrm{~V}$ for 5 minutes while keeping the distance between electrodes at $2 \mathrm{~cm}$. The resultant coating was sintered in the tube furnace at $800^{\circ} \mathrm{C}$. Finally, the samples were ready for characterization to further evaluate the properties of Ti-6Al-4V alloy coated with hydroxyapatite.

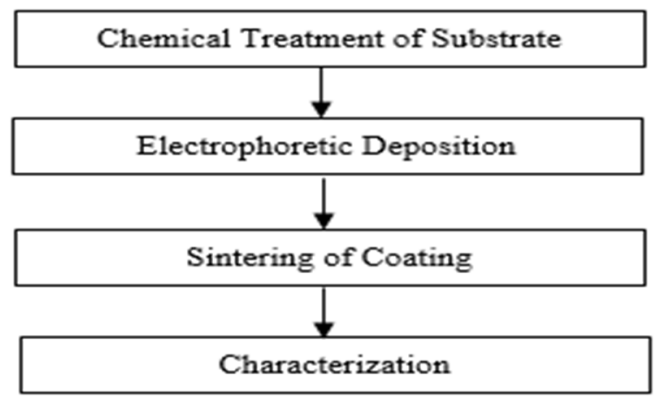

Fig. 2. Process flowchart of coating HAP on Ti-6Al-4V substrate. 


\section{RESULTS AND DISCUSSION}

\section{A. Particle Size Analysis}

We used the BT-9300H laser particle analyzer for the determination of particle size of HAP powder. The results are shown in Figure 3. The average obtained particle size was 25.73 microns with respect to cumulative percentage.

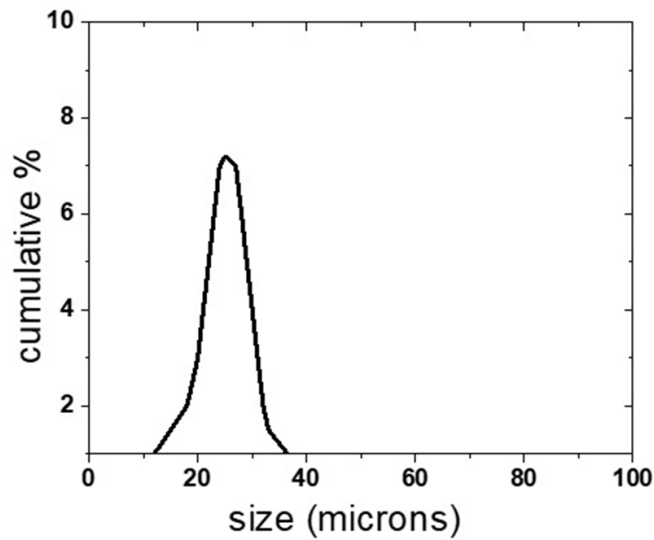

Fig. 3. Average particle size of HAP powder synthesized by bovine bones.

\section{B. XRD Analysis}

The X-pert Pro XRD DY3313 XRD machine operating at $40 \mathrm{kV}$ and $30 \mathrm{~mA}$ using Cuk $\alpha$ radiation was used to analyze the phase of the HAP. The diffraction pattern was recorded over $2 \theta$ at the scanning rate of 0.1 and was performed over the angular range from $10^{\circ}$ to $79^{\circ}$. Figure 4 reveals the XRD spectra of bovine bones calcinated at $1100^{\circ} \mathrm{C}$ which is in good agreement with the standard HAP pattern [46, 47]. The calcinated sample peak at 31.8 confirms the formation of hydroxyapatite powder. Moreover, the XRD spectra of the chemically treated Ti alloy surface show the presence of $\mathrm{TiO}_{2}$ and coated alloy confirming the presence of the HAP layer on the chemically treated Ti6Al4V

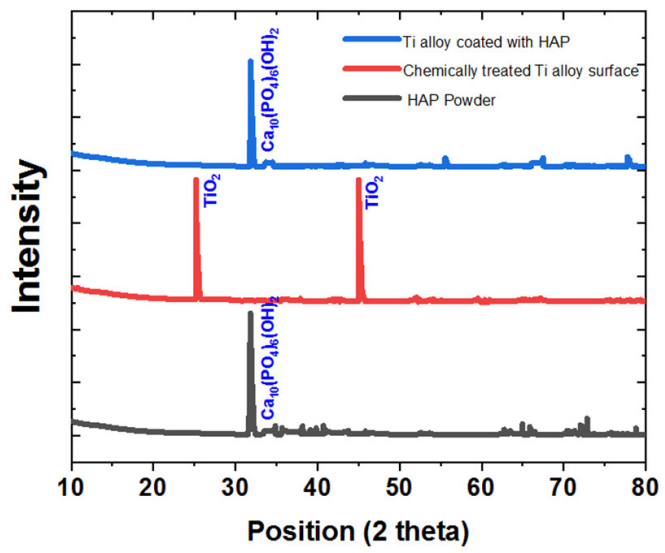

Fig. 4. XRD pattern of synthesised HAP, chemically treated surface and Titanium alloy coated with HAP powder after sintering.

\section{Chemical Composition}

The chemical composition of titanium alloy is found by using an X-ray fluorescence spectroscope (INNOV-X
SYSTEMS) which is comparable to ASTM F136 standard [48]. The results are presented in Table II.

TABLE II. CHEMICAL COMPOSITION USING XRF ANALYSIS

\begin{tabular}{|c|c|c|c|}
\hline Alloy & Titanium & Vanadium & Aluminum \\
\hline ASTMF136 & Balance & $3.5-4.5$ & $5.5-6.75$ \\
\hline Ti6Al4V & Balance & 4.17 & 6.12 \\
\hline
\end{tabular}

\section{Microstructures}

The polarized light microscope OLYMPUS GX51 was used to reveal the microstructure of the as-received samples. It was found that the titanium alloy consists of two different phases: equiaxed Alpha and transformed Beta phase [49] which are shown in Figure 5(a). Figure 5(b) shows the SEM image of the HAP powder. The powder comprises of agglomerated fine particles while the shape of the particles is angular and nonspherical [50]. Figure 5(c) shows Ti6Al4V alloy coated with HAP after sintering which revealed that there was an enhanced linkage and the interconnection of HAP powders that exist on the coated surface morphology [51]. Figure 5(d) shows the HAP coated on Ti6A14V after the immersion in SBF [52].

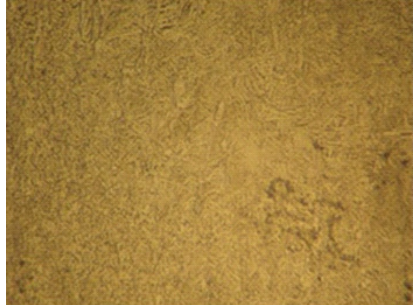

(a)

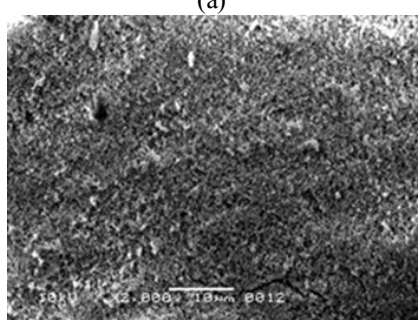

(c)

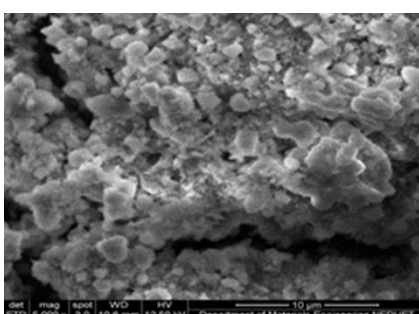

(b)

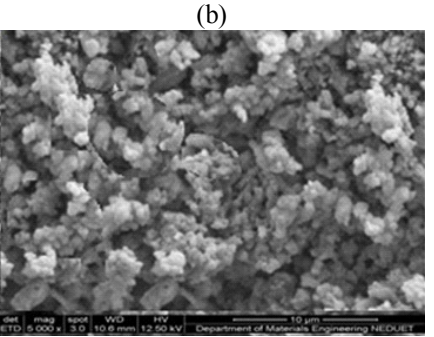

(d)
Fig. 5. (a) Optical structure of as received sample. (b) SEM image of the produced HAP powder. (c) Ti6Al4V coated with HAP and sintered at $800^{\circ} \mathrm{C}$. (d) After immersion in SBF solution.

\section{E. Hardness}

Micro Vickers hardness tester (DIN EN 6507) was used to examine the hardness of bare and coated Ti6Al4V alloy by applying a load of $500 \mathrm{~g}$ with a dwell time of $10 \mathrm{~s}$. The results are shown in Table III. A significant increase in hardness value of $468 \mathrm{HV}$ was obtained for a coated sample as compared to the pristine sample with a hardness value of $340 \mathrm{HV}$. The Ti-based alloy produced a high hardness value which is a major requirement in being compatible with the body environment.

TABLE III. HARDNESS RESULTS

\begin{tabular}{|c|c|}
\hline Alloy & Hardness (HV) \\
\hline Ti6Al4V (before coating) & 340 \\
\hline Ti6Al4V (after coating) & 468 \\
\hline
\end{tabular}




\section{F. Corrosion Behavior}

\section{1) Immersion Test of Coated Samples in SBF}

The coated samples of the HAP were immersed in Simulated Body Fluid (SBF) solution which was prepared according the procedure defined in [40]. The chemical composition of the SBF solution is shown in Table IV. The characterization was based upon the $\mathrm{pH}$ scale. For comparative analysis, the $\mathrm{pH}$ of the solution was measured before immersion and was found to be 7.4. The sample was then immersed in the solution enclosed in a glass beaker at $37^{\circ} \mathrm{C}$ for 7 days. Agitations and vibrations were provided to the beaker to create an artificial environment of fluid movement around the coating. After a passage of the prescribed time, the sample was removed from the solution. The solution $\mathrm{pH}$ was measured after the immersion and was found to be the same as before, i.e. 7.4. Therefore it was confirmed that no exchange of ions took place between the sample and SBF.

TABLE IV. CHEMICAL COMPOSITION OF THE SBF SOLUTION

\begin{tabular}{|c|c|c|}
\hline S.No. & Chemicals & Amount \\
\hline 1 & Sodium chloride & $6.559 \mathrm{~g}$ \\
\hline 2 & Sodium bicarbonate & $2.26 \mathrm{~g}$ \\
\hline 3 & Potassium chloride & $0.3773 \mathrm{~g}$ \\
\hline 4 & Di potassium phosphate tri hydrate & $0.1496 \mathrm{~g}$ \\
\hline 5 & Magnesium chloride hexa hydrate & $0.3411 \mathrm{~g}$ \\
\hline 6 & Hydrochloric acid & $10 \mathrm{ml}$ \\
\hline 7 & Calcium chloride dehydrate & $0.3635 \mathrm{~g}$ \\
\hline 8 & Di sodium sulphate & $0.0731 \mathrm{~g}$ \\
\hline 9 & Cyano hydride tri methanol & $6.0662 \mathrm{~g}$ \\
\hline
\end{tabular}

\section{2) FTIR}

FTIR (Perkin Elmer spectrum one system) was used to identify the functional groups of HAP coated samples in the area of $400-4000 \mathrm{~cm}^{-1}$. The FTIR spectra before and after the immersion in SBF solution is shown in Figures 6 and 7. The $\mathrm{PO}_{4}^{3-}$ group displays peaks at 560 and $600 \mathrm{~cm}^{-1}$ and at 1000 $1100 \mathrm{~cm}^{-1}$. The peak at about $2600-3600 \mathrm{~cm}^{-1}$ links to the hydrated $\mathrm{OH}^{-}$ion of HA [53]. The peak from 2000 to $2200 \mathrm{~cm}^{-1}$ shows the stretching of P-O-H [54]. The peak at $1490 \mathrm{~cm}^{-1}$ matches $\mathrm{CO}_{3}{ }^{2-}$ which specifies that HAP is a carbonated-apatite (HCA) [55]. The representative peaks of $\mathrm{PO}_{4}{ }^{3-}$ appear at 1090, 1014 , and $590 \mathrm{~cm}^{-1}$. The peak at $1650 \mathrm{~cm}^{-1}$ shows the presence of $\mathrm{H}_{2} \mathrm{O}$ [54].

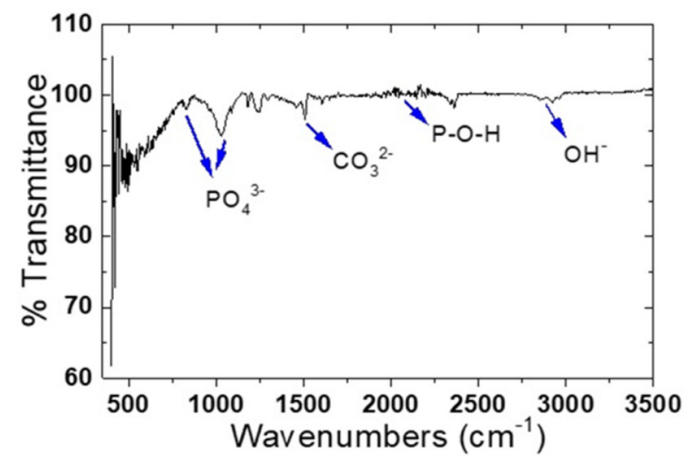

Fig. 6. FTIR spectra of Titanium alloy coated with HAP powder after the immersion in SBF solution.

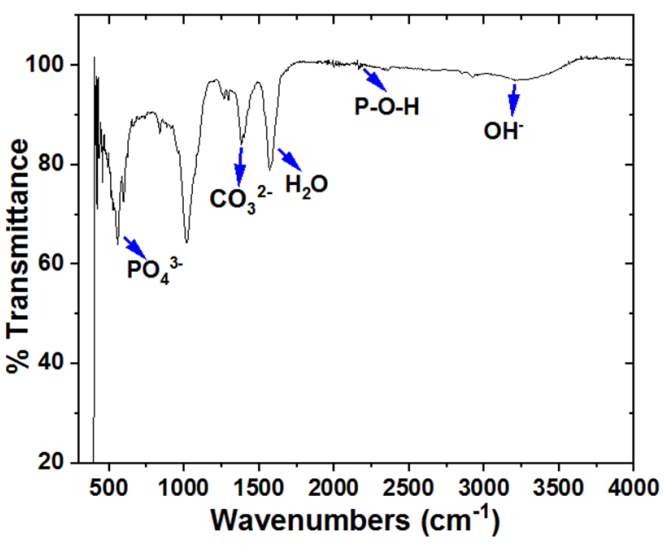

Fig. 7. FTIR spectra of the Titanium alloy coated with HAP powder before the immersion in SBF solution.

\section{3) Potentiostat Test}

Corrosion tests were conducted to find out the corrosion rate of the coated samples. The tests were conducted with a GAMRY potentiostat having a counter electrode (graphite) and a reference electrode (hydrogen) using Tafel. The corrosion rate was determined in an artificially created human body environment called SBF. The Tafel curve of the bare and coated sample is shown in Figure 8. The samples (i.e. the working electrode) were prepared according to the standard ASTM G108-94 analyzed at $37^{\circ} \mathrm{C}$ using voltage ranges between -0.3 and $0.3 \mathrm{~V}$. Tafel curves were plotted at a rate of $1 \mathrm{mv} / \mathrm{sec}$ to find the current density and potential. Figure 8 also shows the potentiodynamic curve for bare Ti6A14V alloy having a current potential of $-240 \mathrm{~V}$ and current density of $1.63 \times 10^{-4} \mu \mathrm{A} / \mathrm{cm}^{2}$. Hence, the corrosion current density (I corr) in the passive zone shifted down from $252 \mathrm{nA}$ to $701 \mathrm{nA}$ and the corrosion potential ( $E_{\text {corr }}$ ) from $-0.24 \mathrm{~V}$ to $0.25 \mathrm{~V}$. The corrosion rate for HAP coated substrate was decreased as $11.95 \times 10^{-3} \mathrm{mpy}$ from $33.53 \times 10^{-3} \mathrm{mpy}$ for the bare Ti6Al4V alloy. The HAP coating consequence on Ti6Al4V alloy infers that the coating shows minimum release of metallic ions in SBF solution [14].

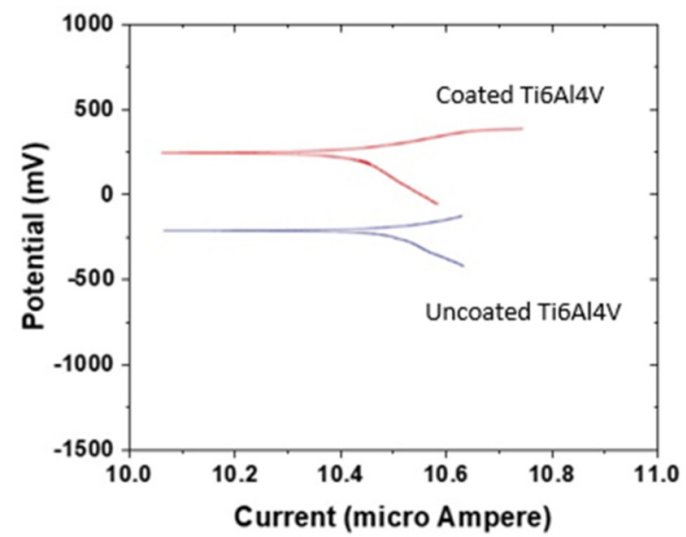

Fig. 8. Tafel curve of coated and uncoated Titanium alloy.

\section{G. Adhesion}

For evaluating the adhesion of the coated samples we used the scratch tester machine M-TGN80 having diamond intender 
landed on the coated substrate producing an indent on the substrate surface up to a maximum load of $60 \mathrm{~N}$ as shown in Figure 9. The result shows an excellent strength for the coating [56]. The morphological measurements were taken in the stereo microscope under low magnifications $(5 \mathrm{X})$ which reveal the distances of the crack from various aspects.

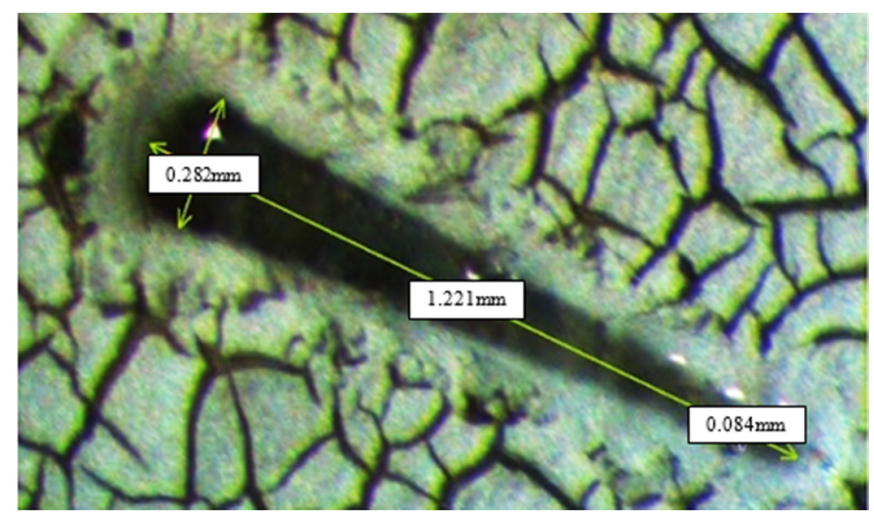

Fig. 9. Magnified scratch marked with the Adhesion tester.

\section{CONCLUSION}

Hydroxyapatite is the furthermost noticeable inorganic substance for biomedical applications. Research showed that natural HAP from bovine bones can be synthesized by using the thermal decomposition method. From this study, no significant difference was observed between bovine bonederived HAP and naturally occurring HAP. HAP powder electrophoretically deposited on Ti-6Al-4V alloy was used as substrate. The characterization of the coated sample confirmed that the coating enhanced the osseointegration properties of the implant. Moreover, the hardness of the coated samples was observed to be increased up to $35 \%$ as compared to the pristine samples. The corrosion rate for coated samples was found to be decreasing from $33.53 \times 10^{-3} \mathrm{mpy}$ to $11.95 \times 10^{-3} \mathrm{mpy}$. Therefore, the resultant structures show that our produced samples can be used for a wide variety of medical applications with minimal expenses.

\section{ACKNOWLEDGMENT}

The authors wish to express their gratitude to the Higher Education Commission of Pakistan for the funding under the NRPU "National Research Program for Universities 2017-18" grand. We also thank the NED University of Engineering and Technology for providing us the platform to carry out this work.

\section{REFERENCES}

[1] M. T. Mohammed, Z. A. Khan, and A. N. Siddiquee, "Surface Modifications of Titanium Materials for developing Corrosion Behavior in Human Body Environment: A Review," Procedia Materials Science, vol. 6, pp. 1610-1618, Jan. 2014, https://doi.org/10.1016/j.mspro. 2014.07.144.

[2] F. Trevisan et al., "Additive manufacturing of titanium alloys in the biomedical field: processes, properties and applications," Journal of Applied Biomaterials \& Functional Materials, vol. 16, no. 2, pp. 57-67, Apr. 2018, https://doi.org/10.5301/jabfm.5000371.
[3] M. Lepicka and M. Gradzka-Dahlke, "Surface modification of Ti6Al4V titanium alloy for biomedical applications and its effect on tribological performance - A review," Reviews on Advanced Materials Science, vol. 46 , no. 1 , pp. 86-103, 2016.

[4] J. W. Nicholson, "Titanium Alloys for Dental Implants: A Review," Prosthesis, vol. 2, no. 2, pp. 100-116, Jun. 2020, https://doi.org/ 10.3390/prosthesis2020011.

[5] W. Liu, S. Liu, and L. Wang, "Surface Modification of Biomedical Titanium Alloy: Micromorphology, Microstructure Evolution and Biomedical Applications," Coatings, vol. 9, no. 4, Apr. 2019, Art. no. 249, https://doi.org/10.3390/coatings9040249.

[6] M. L. Lourenço, G. C. Cardoso, K. dos S. J. Sousa, T. A. G. Donato, F. M. L. Pontes, and C. R. Grandini, "Development of novel Ti-Mo-Mn alloys for biomedical applications," Scientific Reports, vol. 10, no. 1, p. 6298, Apr. 2020, https://doi.org/10.1038/s41598-020-62865-4.

[7] M. Kulkarni, A. Mazare, and P. Schmuki, "Biomaterial Surface Modification Of Titanium and Titanium Alloys for Medical Applications," in Nanomedicine, Cheshire, UK: One Central Press, 2014, pp. 111-136.

[8] M. J. Jackson, J. Kopac, M. Balazic, D. Bombac, M. Brojan, and F. Kosel, "Titanium and Titanium Alloy Applications in Medicine," in Surgical Tools and Medical Devices, W. Ahmed and M. J. Jackson, Eds. New York, NY, USA: Springer, 2016, pp. 475-517.

[9] Damisih, I. N. Jujur, J. Sah, Agustanhakri, and D. H. Prajitno, "Characteristics microstructure and microhardness of cast Ti-6Al-4V ELI for biomedical application submitted to solution treatment," AIP Conference Proceedings, vol. 1964, no. 1, May 2018, Art. no. 020037, https://doi.org/10.1063/1.5038319.

[10] D. Aroussi, B. Aour, and A. S. Bouaziz, "A Comparative Study of 316L Stainless Steel and a Titanium Alloy in an Aggressive Biological Medium," Engineering, Technology \& Applied Science Research, vol. 9, no. 6, pp. 5093-5098, Dec. 2019, https://doi.org/10.48084/etasr.3208.

[11] S.-W. Lee et al., "Hydroxyapatite and Collagen Combination-Coated Dental Implants Display Better Bone Formation in the Peri-Implant Area Than the Same Combination Plus Bone Morphogenetic Protein-2Coated Implants, Hydroxyapatite Only Coated Implants, and Uncoated Implants," Journal of Oral and Maxillofacial Surgery, vol. 72, no. 1, pp. 53-60, Jan. 2014, https://doi.org/10.1016/j.joms.2013.08.031.

[12] A. Boudjemline, M. Boujelbene, and E. Bayraktar, "Surface Quality of Ti-6Al-4V Titanium Alloy Parts Machined by Laser Cutting," Engineering, Technology \& Applied Science Research, vol. 10, no. 4, pp. 6062-6067, Aug. 2020, https://doi.org/10.48084/etasr.3719.

[13] F. Zhang, A. Weidmann, J. B. Nebe, U. Beck, and E. Burkel, "Preparation, microstructures, mechanical properties, and cytocompatibility of TiMn alloys for biomedical applications," Journal of Biomedical Materials Research Part B: Applied Biomaterials, vol. 94B, no. 2, pp. 406-413, 2010, https://doi.org/10.1002/jbm.b.31668.

[14] P. Shanmugapriya, V. Srinivasan, B. Karthikeyan, and T.V.Rajamurugan, "Surface modification of nanocomposite $\mathrm{Al} 2 \mathrm{O} 3 / \mathrm{Gr} / \mathrm{HAP}$ coating for improving wear and corrosion behaviour on Ti-6Al-4V alloy using sol-gel technique," Multiscale and Multidisciplinary Modeling, Experiments and Design, Jan. 2021, https://doi.org/10.1007/s41939-021-00089-3.

[15] L. Xia, Y. Xie, B. Fang, X. Wang, and K. Lin, "In situ modulation of crystallinity and nano-structures to enhance the stability and osseointegration of hydroxyapatite coatings on Ti-6Al-4V implants," Chemical Engineering Journal, vol. 347, pp. 711-720, Sep. 2018, https://doi.org/10.1016/j.cej.2018.04.045.

[16] X. Liu, S. Chen, J. K. H. Tsoi, and J. P. Matinlinna, "Binary titanium alloys as dental implant materials - a review," Regenerative Biomaterials, vol. 4, no. 5, pp. 315-323, Oct. 2017, https://doi.org/ $10.1093 / \mathrm{rb} / \mathrm{rbx} 027$.

[17] M. Alqattan, L. Peters, Y. Alshammari, F. Yang, and L. Bolzoni, "Antibacterial Ti-Mn-Cu alloys for biomedical applications," Regenerative Biomaterials, vol. 8, Feb. 2021, Art. no. rbaa050, https://doi.org/10.1093/rb/rbaa050.

[18] T. Hryniewicz, K. Rokosz, J. Valicek, and R. Rokicki, "Effect of magnetoelectropolishing on nanohardness and Young's modulus of 
titanium biomaterial," Materials Letters, vol. 83, pp. 69-72, Sep. 2012, https://doi.org/10.1016/j.matlet.2012.06.010.

[19] L. Benea, E. Mardare-Danaila, M. Mardare, and J.-P. Celis, "Preparation of titanium oxide and hydroxyapatite on $\mathrm{Ti}-6 \mathrm{Al}-4 \mathrm{~V}$ alloy surface and electrochemical behaviour in bio-simulated fluid solution," Corrosion Science, vol. 80, pp. 331-338, Mar. 2014, https://doi.org/10.1016/ j.corsci.2013.11.059.

[20] J. Jakubowicz, "Special Issue: Ti-Based Biomaterials: Synthesis, Properties and Applications," Materials, vol. 13, no. 7, p. 1696, Jan. 2020, https://doi.org/10.3390/ma13071696.

[21] U. F. Gunputh and H. Le, "A Review of In-Situ Grown Nanocomposite Coatings for Titanium Alloy Implants," Journal of Composites Science, vol. 4, no. 2, Jun. 2020, Art. no. 41, https://doi.org/10.3390/jcs4020041.

[22] U.-W. Jung et al., "Surface characteristics of a novel hydroxyapatitecoated dental implant," Journal of Periodontal \& Implant Science, vol. 42, no. 2, pp. 59-63, Apr. 2012, https://doi.org/10.5051/jpis.2012.42. 2.59 .

[23] Y. Kirmanidou et al., "New Ti-Alloys and Surface Modifications to Improve the Mechanical Properties and the Biological Response to Orthopedic and Dental Implants: A Review," BioMed Research International, vol. 2016, Jan. 2016, Art. no. e2908570, https://doi.org/ $10.1155 / 2016 / 2908570$.

[24] F. Findik, "Surface Treatment of Ti-Alloys," Current Trends in Biomedical Engineering \& Biosciences, vol. 15, no. 3, Jun. 2018, Art. no. 555911, https://doi.org/10.19080/CTBEB.2018.15.555911.

[25] J. Sharan, S. V. Lale, V. Koul, M. Mishra, and O. P. Kharbanda*, "An Overview of Surface Modifications of Titanium and its Alloys for Biomedical Applications," Trends in Biomaterials \& Artificial Organs, vol. 29, no. 2, pp. 176-187, Jun. 2015.

[26] A. Jaafar, C. Hecker, P. Arki, and Y. Joseph, "Sol-Gel Derived Hydroxyapatite Coatings for Titanium Implants: A Review," Bioengineering, vol. 7, no. 4, Dec. 2020, Art. no. 127, https://doi.org/ 10.3390/bioengineering7040127.

[27] R. Family, M. Solati-Hashjin, S. Namjoy Nik, and A. Nemati, "Surface modification for titanium implants by hydroxyapatite nanocomposite," Caspian Journal of Internal Medicine, vol. 3, no. 3, pp. 460-465, 2012.

[28] B.-O. Taranu, A. I. Bucur, and I. Sebarchievici, "Three-step procedure for the deposition of hydroxyapatite coatings," Journal of Coatings Technology and Research, vol. 17, no. 4, pp. 1075-1082, Jul. 2020, https://doi.org/10.1007/s1 1998-020-00318-3.

[29] M. H. Fathi and F. Azam, "Novel hydroxyapatite/tantalum surface coating for metallic dental implant," Materials Letters, vol. 61, no. 4, pp. 1238-1241, Feb. 2007, https://doi.org/10.1016/j.matlet.2006.07.013.

[30] Q. Chen and G. A. Thouas, "Metallic implant biomaterials," Materials Science and Engineering: R: Reports, vol. 87, pp. 1-57, Jan. 2015, https://doi.org/10.1016/j.mser.2014.10.001.

[31] S. S. Bhasin, E. Perwez, S. Sachdeva, and R. Mallick, "Trends in prosthetic biomaterials in implant dentistry," Journal of the International Clinical Dental Research Organization, vol. 7, no. 3, pp. 148-159, Dec. 2015, https://doi.org/10.4103/2231-0754.172936.

[32] M. Manoj, R. Subbiah, D. Mangalaraj, N. Ponpandian, C. Viswanathan, and K. Park, "Influence of Growth Parameters on the Formation of Hydroxyapatite (HAp) Nanostructures and Their Cell Viability Studies," Nanobiomedicine, vol. 2, Jan. 2015, Art. no. 2, https://doi.org/ $10.5772 / 60116$.

[33] M. Lukaszewska-Kuska, P. Krawczyk, A. Martyla, W. Hedzelek, and B. Dorocka-Bobkowska, "Hydroxyapatite coating on titanium endosseous implants for improved osseointegration: Physical and chemical considerations," Advances in Clinical and Experimental Medicine: Official Organ Wroclaw Medical University, vol. 27, no. 8, pp. 10551059, Aug. 2018, https://doi.org/10.17219/acem/69084.

[34] H. Daugaard, B. Elmengaard, J. E. Bechtold, T. Jensen, and K. Soballe, "The effect on bone growth enhancement of implant coatings with hydroxyapatite and collagen deposited electrochemically and by plasma spray," Journal of Biomedical Materials Research Part A, vol. 92A, no. 3, pp. 913-921, 2010, https://doi.org/10.1002/jbm.a.32303.

[35] A. Szczes, L. Holysz, and E. Chibowski, "Synthesis of hydroxyapatite for biomedical applications," Advances in Colloid and Interface Science, vol. 249, pp. 321-330, Nov. 2017, https://oi.org/10.1016/j.cis.2017.04.007.

[36] A. Fihri, C. Len, R. S. Varma, and A. Solhy, "Hydroxyapatite: A review of syntheses, structure and applications in heterogeneous catalysis," Coordination Chemistry Reviews, vol. 347, pp. 48-76, Sep. 2017, https://doi.org/10.1016/j.ccr.2017.06.009.

[37] K. Kuroda and M. Okido, "Hydroxyapatite Coating of Titanium Implants Using Hydroprocessing and Evaluation of Their Osteoconductivity," Bioinorganic Chemistry and Applications, vol. 2012, Feb. 2012, Art. no. e730693, https://doi.org/10.1155/2012/730693.

[38] P. Habibovic, F. Barrere, C. A. V. Blitterswijk, K. de Groot, and P. Layrolle, "Biomimetic Hydroxyapatite Coating on Metal Implants," Journal of the American Ceramic Society, vol. 85, no. 3, pp. 517-522, 2002, https://doi.org/10.1111/j.1151-2916.2002.tb00126.x.

[39] V. Rattan, T. S. Sidhu, and M. Mittal, "An Overview of Hydroxyapatite Coated Titanium Implants," Asian Journal of Engineering and Applied Technology, vol. 1, no. 2, pp. 40-43, Jul. 2012.

[40] G. Ciobanu and M. Harja, "Investigation on hydroxyapatite coatings formation on titanium surface," IOP Conference Series: Materials Science and Engineering, vol. 444, Nov. 2018, Art. no. 032007, https://doi.org/10.1088/1757-899X/444/3/032007.

[41] M. Hadidi et al., "Electrophoretic-deposited hydroxyapatite-copper nanocomposite as an antibacterial coating for biomedical applications," Surface and Coatings Technology, vol. 321, pp. 171-179, Jul. 2017, https://doi.org/10.1016/j.surfcoat.2017.04.055.

[42] M. Komath, P. Rajesh, C. V. Muraleedharan, H. K. Varma, R. Reshmi, and M. K. Jayaraj, "Formation of hydroxyapatite coating on titanium at $200^{\circ} \mathrm{C}$ through pulsed laser deposition followed by hydrothermal treatment," Bulletin of Materials Science, vol. 2, no. 34, pp. 389-399, 2011, https://doi.org/10.1007/s12034-011-0069-5.

[43] M. Furko, K. Balazsi, and C. Balazsi, "Comparative study on preparation and characterization of bioactive coatings for biomedical applications-A review on recent patents and literature," Reviews on Advanced Materials Science, vol. 48, no. 1, pp. 25-51, 2017.

[44] K. D. Patel, R. K. Singh, J.-H. Lee, and H.-W. Kim, "Electrophoretic coatings of hydroxyapatite with various nanocrystal shapes," Materials Letters, vol. 234, pp. 148-154, Jan. 2019, https://doi.org/10.1016/ j.matlet.2018.09.066.

[45] L. Sorkhi, M. Farrokhi-Rad, and T. Shahrabi, "Electrophoretic Deposition of Hydroxyapatite-Chitosan-Titania on Stainless Steel 316 L," Surfaces, vol. 2, no. 3, pp. 458-467, Sep. 2019, https://doi.org/ $10.3390 /$ surfaces 2030034 .

[46] M. Gardon, A. Concustell, S. Dosta, N. Cinca, I. G. Cano, and J. M. Guilemany, "Improved bonding strength of bioactive cermet Cold Gas Spray coatings," Materials Science and Engineering: C, vol. 45, pp. 117-121, Dec. 2014, https://doi.org/10.1016/j.msec.2014.08.053.

[47] M. Rana, N. Akhtar, S. Rahman, H. Jamil, and S. Asaduzzaman, "Extraction of Hydroxyapatite from Bovine and Human Cortical Bone by Thermal Decomposition and Effect of Gamma Radiation: A Comparative Study," International Journal of Complementary \& Alternative Medicine, vol. 8, no. 3, Aug. 2017, Art. no. 263, https://doi.org/10.15406/ijcam.2017.08.00263.

[48] R. C. Rocha et al., "Surface, microstructural, and adhesion strength investigations of a bioactive hydroxyapatite-titanium oxide ceramic coating applied to Ti-6Al-4V alloys by plasma thermal spraying," Materials Research, vol. 21, no. 4, 2018, Art. no. e20171144, https://doi.org/10.1590/1980-5373-mr-2017-1144.

[49] V. Jordanovova, M. Losertova, M. Stencek, T. Lukasova, G. Simha Martynkova, and P. Peikertova, "Microstructure and Properties of Nanostructured Coating on Ti6Al4V," Materials, vol. 13, no. 3, Jan. 2020, Art. no. 708, https://doi.org/10.3390/ma13030708.

[50] A. K. Khanra, H. C. Jung, S. H. Yu, K. S. Hong, and K. S. Shin, "Microstructure and mechanical properties of Mg-HAP composites," Bulletin of Materials Science, vol. 33, no. 1, pp. 43-47, Feb. 2010, https://doi.org/10.1007/s12034-010-0006-z.

[51] H. Naseri, M. Ghatee, A. Yazdani, M. Mohammadi, and S. Manafi, "Characterization of the 3YSZ/CNT/HAP coating on the Ti6Al4V alloy by electrophoretic deposition," Journal of Biomedical Materials 
Research Part B: Applied Biomaterials, https://doi.org/10.1002/jbm.b. 34799.

[52] P. A. F. Sossa et al., "Comparative study between natural and synthetic Hydroxyapatite: structural, morphological and bioactivity properties," Materia (Rio de Janeiro), vol. 23, no. 4, 2018, https://doi.org/10.1590/ s1517-707620180004.0551.

[53] G. C. Gomes, F. F. Borghi, R. O. Ospina, E. O. López, F. O. Borges, and A. Mello, "Nd:YAG $(532 \mathrm{~nm})$ pulsed laser deposition produces crystalline hydroxyapatite thin coatings at room temperature," Surface and Coatings Technology, vol. 329, pp. 174-183, Nov. 2017, https://doi.org/10.1016/j.surfcoat.2017.09.008.

[54] A. A. Abdeltawab, M. A. Shoeib, and S. G. Mohamed, "Electrophoretic deposition of hydroxyapatite coatings on titanium from dimethylformamide suspensions," Surface and Coatings Technology, vol. 206, no. 1, pp. 43-50, Oct. 2011, https://doi.org/10.1016/j.surfcoat. 2011.06 .034 .

[55] H. Gheisari and E. Karamian, "Preparation and characterization of hydroxyapatite reinforced with hardystonite as a novel bionanocomposite for tissue engineering," Nanomedicine Journal, vol. 2, no. 2, pp. 141-152, Apr. 2015, https://doi.org/10.7508/nmj.2015.02.006.

[56] L. Mohan, D. Durgalakshmi, M. Geetha, T. S. N. Sankara Narayanan, and R. Asokamani, "Electrophoretic deposition of nanocomposite (HAp+TiO2) on titanium alloy for biomedical applications," Ceramics International, vol. 38, no. 4, pp. 3435-3443, May 2012, https://doi.org/ 10.1016/j.ceramint.2011.12.056.

\section{AUTHORS PROFILE}

Shafaq Asrar is currently serving as a Lecturer, and a Ph.D scholar in the department of Metallurgy Engineering, NED University.

Muhammad Tufail is currently serving as a Pro-Vice Chancellor of NED University. He has acquired his Ph.D from the University of Nottingham, UK

Ali Dad Chandio is currently serving as a Chairman of the Metallurgical Engineering Department, NED University. He has acquired his Ph.D from the University of Manchester, UK 